\title{
Relationship between in-Hospital Mortality and Inflammation Markers in Covid-19 Patients with the Diagnosis of Coronary Artery Disease
}

\section{Koroner Arter Hastalığı Tanısı Alan Covid-19 Hastalarında Hastane İçi Mortalite ile İnflamasyon Belirteçleri Arasındaki iliş̧ki}

 \\ 'Department of Cardiology' Faculty of Medicine, Çanakkale Onsekiz Mart University' Çanakkale, Turkey \\ 2Department of Infectious Diseases and Clinical Microbiology' Çanakkale Onsekiz Mart University' Çanakkale, Turkey
}

\begin{abstract}
Introduction: Inflammation plays an important role in the basis of coronary artery diseases and their adverse outcomes. Neutrophillymphocyte ratio (NLR), Systemic Immune Inflammation Index (SII) and C-reactive protein (CRP) are simple and useful markers that reflect the inflammatory state. Our study evaluated the usability of these markers in predicting in-hospital mortality in patients with Covid-19 with the diagnosis of coronary artery disease.
\end{abstract}

Material and Method: Our study population consisted of 111 (48 male, 63 female) newly diagnosed patients with Covid-19. Neutrophil-lymphocyte ratio (NLR) was estimated using neutrophil $(\mathrm{N})$, and lymphocyte (L) counts and the systemic immune inflammation index SII (NxP / L) was calculated using N, L and platelet (P) values. The relationship of NLR, SII and CRP values with in-hospital mortality was investigated.

Results: During the treatment process, 16 patients exited. Any statistically significant intergroup difference was not observed as for SIl and NLR values obtained by their use in combination $(p=0.872, p=0.979$, respectively), CRP values were statistically significant in the group with in-hospital mortality $(p<0.001)$. In logistic regression analysis, CRP (odds ratio [OR] $=1.078,95 \%$ confidence interval $[\mathrm{Cl}]: 1.0225-1.133, \mathrm{p}=0.003)$ was associated with in-hospital mortality. In ROC analysis, the cut-off values of $3.1 \mathrm{mg} / \mathrm{dL}$, for CRP were significant with $87 \%$ sensitivity and $58 \%$ specificity in predicting in-hospital mortality $(p<0.001)$.

Conclusions: CRP levels are associated with in-hospital mortality in patients with Covid-19 who had also received coronary artery disease with a history of coronary intervention.

Keywords: Covid-19, mortality, coronary artery disease
Öz

Giriş: Enflamasyon, koroner arter hastalıklarının temelinde ve olumsuz sonlanımlarında önemli rol oynar. Nötrofil-lenfosit oranı (NLR), sistemik immün inflamasyon indeksi (SII) ve CRP ise inflamatuar durumu yansıtan basit ve kullanışı belirteçlerdir. Çalışmamızın amacı bu belirteçlerin koroner arter hastalı̆ı tanılı Covid-19 hastalarında hastane içi mortaliteyi öngörmede kullanılabilirliğini değerlendirmeyi amaçladık.

Gereç ve Yöntem: Çalışmamız 111 (48 erkek, 63 kadın) yeni tanı Covid-19 hastasından oluşuyordu. Nötrofil (N), lenfosit (L) değerleri kullanılarak NLR (N/L) ve N,L ve trombosit (P) değerleri kullanılarak sistemik immün inflamasyon indeksi SII (NxP / L) elde edildi. NLR, SIl ve CRP değerlerinin hastane içi mortaliteyle olan ilişkileri incelendi.

Bulgular:Tedavi sürecinde 16 hastada ölüm izlendi. N, L ve P değerleri hayatını kaybenler ve şifa ile taburcu olan grup arasında kıyaslandığında istatiksel farklıliklar izlenmedi ( $p=0.971, p=0.256, p=0.759$ sırasıyla). Bunların kombinasyonu ile elde edilen SII ve NLR değerleri için gruplar arasında istatiksel farklılıklar izlenmezken ( $\mathrm{p}=0.872, \mathrm{p}=0.979$ sırasılya), CRP değerleri ise hastane içi ölüm izlenen grupta istatiksel olarak anlamlıydı ( $p<0.001$ ). Logistik regresyon analizinde, CRP'nin (odds oranı $[\mathrm{OO}]=1.078, \% 95$ güven aralığı [GA]: 1.0225-1.133, $\mathrm{p}=0.003$ ) hastane içi mortaliteyle ilişkkili olduğu gösterildi. ROC analizinde hastane içi mortaliteyi tahmin etmede CRP için $3.1 \mathrm{mg} / \mathrm{dL}$ kestirim değerleri \%87 hassasiyet ve \%58 özgüllük ile anlamlı bulundu $(p<0.001)$.

Sonuç: Koroner girişim öyküsü olan koroner arter hastalığı tanıı Covid-19 hastalarında CRP seviyeleri hastane içi ölümle ilişkilidir.

Anahtar kelimeler: Covid-19, ölüm, koroner arter hastalığı

Corresponding (iletişim): Uğur Küçük, Barbaros Street Terzioglu Campus B Block No: 4, Onsekiz Mart University Faculty of Medicine, Department of Cardiology, Çanakkale, Turkey

E-mail (E-posta): drugurkucuk@hotmail.com

Received (Geliş Tarihi): 27.01.2021 Accepted (Kabul Tarihi): 18.02.2021 


\section{INTRODUCTION}

Covid-19 (coronavirus disease 2019) has affected the whole world in a short time and caused a pandemic. ${ }^{[1]}$ Although there is no prophylactic treatment so far there are various treatment algorithms related to the disease. Underlying additional diseases such as respiratory failure, thromboembolic events and cardiovascular diseases are the main factors that negatively affect the treatment process. ${ }^{[2]}$

Especially, coagulopathies are very frequently seen in patients with Covid-19 and can cause unwanted cerebrovascular and coronary events. Studies have shown that clinical features such as thrombocytopenia, anemia and low oxygen saturation are associated with increased in-hospital mortality in patients with Covid-19 disease. ${ }^{[3,4]}$

When the current pandemic period and before are evaluated, cardiovascular diseases (CVD) have high mortality and morbidity despite developments in medical and technological fields. ${ }^{[5]}$ In particular, coronary artery diseases (CADs) have the most important percentage in this group, and there are various parameters (such as uric acid, neutrophils, C-reactive protein (CRP) with proven usability in in-hospital and longterm prognoses. ${ }^{[6]}$ In patients with Covid-19 diseases who also received the diagnosis of $C A D$, the parameters that can be used as predictors of in-hospital mortality and their reference values have not been elucidated yet.

Our study aims to investigate the relationship between inhospital mortality in patients with Covid-19 disease who also received the diagnosis of $C A D$, and inflammation indicators that can be measured under any laboratory conditions.

\section{MATERIAL AND METHOD}

A total of 145 consecutive Covid-19 patients who had previously undergone percutaneous coronary intervention with the diagnosis of coronary artery disease were included in the study. Patients with evidence of coronary artery ischemia (patients with newly diagnosed left ventricular wall motion defect, myocardial perfusion scintigraphy and evidence of ischemia in treadmill exercise test) and patients with a history of coronary stent after undergoing coronary angiography were included. RNA detection of SARS-CoV-2 in samples taken from combined throat and nose swabs confirmed the diagnosis of Covid-19 disease. 5 patients with incomplete follow-up data, 24 patients deceased because of non-Covid-19 diseases, and 5 patients with a history of malignant disease were excluded from the study. A total of 111 patients including 48 males and 63 females, were included in the study (Figure 1).

Transthoracic echocardiogram (TTE) was performed on admission. Hemogram and biochemical parameters of all patients were retrieved from laboratory records obtained by studying venous blood samples during hospitalization. Information on which coronary vessel stent was obtained from the patients' past medical archives. Hydroxychloroquine and azithromycin have been formally recommended for the treatment of Covid-19 by the Ministry of Health. While applying the treatments, current recommendations have been applied considering the hospitalization date. In our study, immune plasma was not used since there was no clinical indication. The patients were divided into two groups according to the type of discharge. Those who were discharged from the hospital with complete recovery comprised Group 1, and those who lost their lives during hospitalization constituted Group 2.

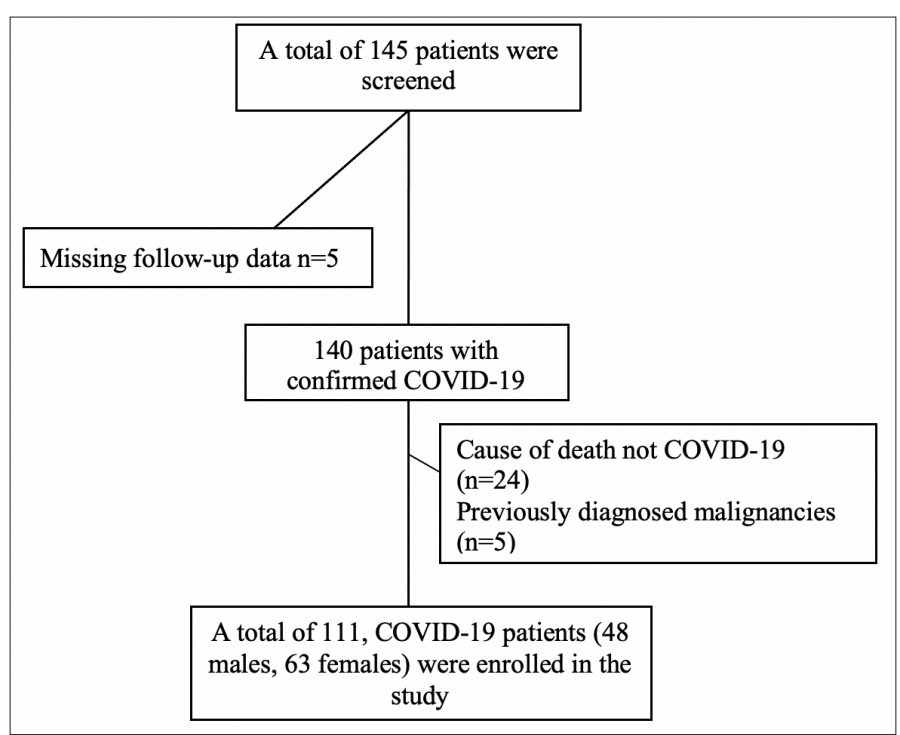

Figure 1. The study's flow chart

Patients who underwent coronary artery bypass graft (CABG) surgery, in-hospital interventions due to newly diagnosed coronary artery disease, those with known heart failure, chronic renal failure, malignant disease, acute cerebrovascular disease, died from infectious diseases other than Covid-19, hospitalized in intensive care unit and individuals younger than 18 years were not included in our study.

The systemic immune inflammation index (SII) was calculated by dividing the value obtained as a result of the multiplication of neutrophil $(N)$ and lymphocyte $(L)$ values by the platelet $(P)$ values. Neutrophil - lymphocyte ratio (NLR) was obtained by dividing the $\mathrm{N}$ values by the $\mathrm{L}$ values.

Ministry of Health and the ethics committee of our institution, and our study was carried out in accordance with Principles of the Helsinki Declaration (Decision no: 2020-14).

\section{Statistical Analysis}

Statistical data were obtained by using SPSS 21.0 (SPSS Inc, Chicago, IL, USA). Kolmogorov - Smirnov test was used to evaluate the distribution of continuous variables. Continuous variables obtained as a result of the analysis were expressed as a mean \pm standard deviation; and categorical variables as percentages and numbers. The t-test and Mann-Whitney $U$ test were used to compare parameters that were, and were not compatible with normal distribution, respectively. 
Chi-square test was used when comparing the odds ratios of categorical variables. Logistic regression analysis was performed to determine the effect of variables. The $95 \%$ confidence intervals were calculated using standardized beta coefficients. The ROC curve was used to evaluate the predictive value of CRP for in-hospital mortality in patients with Covid-19 who also received the diagnosis of CAD. P values below 0.05 were considered statistically significant.

\section{RESULTS}

Our study population consisted of 111 patients diagnosed with Covid-19 (48 males and 63 females; mean age: 71.511 .6 years). In most patients, oxygen therapy was given according to the results of arterial blood gas monitoring under close monitoring. Group 1 patients who were discharged with recovery consisted of 95 patients (42 males and 53 females), while Group 2 consisted of 16 deceased inpatients ( 6 males and 10 females). The demographic and laboratory results of the patients are shown in Table 1. When the variables of HT, DM and age were examined, although there were numerical differences between the groups, any statistical significant differences were not observed. A statistically significant intergroup difference was observed in hemoglobin levels $(p=0.001)$. When NLR and SII values were analyzed between groups, any statistically significant intergroup differences were not observed ( $p>0.05$ for both). CRP values of group 2 patients compared to group 1 patients were found to be statistically significant and statistically significant $(p<0.001)$ (Table 1). There was no statistical significance for LVEF values between groups $(p=0.138)$ (Table 1$)$. As a result of univariate and multivariate regression analysis, a relationship was obtained between in-hospital mortality and CRP and hemoglobin levels in univariate analysis, while multivariate analysis showed that there was only a relationship between CRP levels and mortality (HR: 1.111, 95\% Cl: 1.025-1.204, $\mathrm{p}=0.001$ ) (Table 2). Receiver Operating Characteristic (ROC) curve analysis shows that CRP values higher than 3.1 can predict in-hospital mortality in CAD patients with Covid-19 disease $[(p<0.001)$ (sensitivity, $87 \%$; specificity, 58\%; area under the curve, $0.776 ; 95 \% \mathrm{Cl}$ : 0.646-0.906)] (Figure 2).

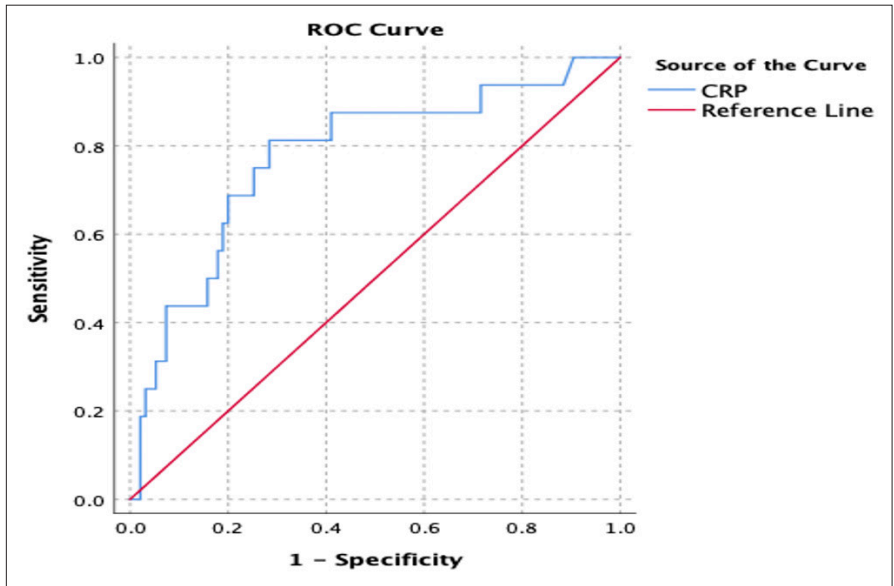

Figure 2. Receiver operating characteristic (ROC) curve of CRP levels for predict in-hospital mortality in coronary artery disease patients with Covid-19 disease

\section{Table 1. General characteristics of the patients}

\begin{tabular}{|c|c|c|c|}
\hline Variables & $\begin{array}{c}\text { Group } 1 \\
(n=95)\end{array}$ & $\begin{array}{c}\text { Group } 2 \\
(n=16)\end{array}$ & $\mathbf{P}$ \\
\hline Age (years) & $71.68 \pm 12$ & $71.06 \pm 9.49$ & 0.844 \\
\hline Female n (\%) & $53(55.8)$ & $10(62.5)$ & 0.614 \\
\hline HT n (\%) & $56(58.9)$ & $9(56.3)$ & 0.840 \\
\hline DM n (\%) & $33(34.7)$ & $4(25)$ & 0.435 \\
\hline Creatinine (mg/dL) & $0.76 \pm 0.17$ & $0.78 \pm 0.13$ & 0.704 \\
\hline Ürik asit & $7.13 \pm 2.97$ & $7.53 \pm 3.50$ & 0.607 \\
\hline LVEF, \% & $52.95 \pm 7.41$ & $55.93 \pm 7.15$ & 0.138 \\
\hline \multicolumn{4}{|l|}{ Main branch stent, $\mathrm{n}(\%)$} \\
\hline LAD & $36(37.9)$ & $8(50)$ & 0.360 \\
\hline$C x$ & $42(44.2)$ & $3(18.8)$ & 0.055 \\
\hline RCA & $17(77.3)$ & $5(31.3)$ & 0.215 \\
\hline WBC count, $\left(\times 10^{3} \mu \mathrm{L}\right)$ & $10.83 \pm 5.67$ & $10.60 \pm 5.71$ & 0.879 \\
\hline Lymphocyte count $\left(\times 10^{3} / \mathrm{L}\right)$ & $1.34 \pm 0.90$ & $1.08 \pm 0.67$ & 0.256 \\
\hline Neutrophil count, $\left(\times 10^{3} / \mathrm{L}\right)$ & $8.44 \pm 5.59$ & $8.38 \pm 5.32$ & 0.971 \\
\hline Hemoglobin g/dL & $13.23 \pm 2.36$ & $11 \pm 2.77$ & 0.001 \\
\hline Monocyte count $\left(10^{3} / \mathrm{mm}^{3}\right)$ & $0.78 \pm 0.41$ & $0.70 \pm 0.43$ & 0.456 \\
\hline Trombosit count $\left(\times 10^{3} \mu \mathrm{L}\right)$ & 248.12109 .64 & $238.75 \pm 130.992$ & 0.759 \\
\hline NLR & $11.26 \pm 13.94$ & $12.21 \pm 11.80$ & 0.797 \\
\hline SII & $294 \pm 428$ & $313 \pm 390$ & 0.872 \\
\hline $\mathrm{CRP}, \mathrm{mg} / \mathrm{dL}$ & $5.74 \pm 8.77$ & $14.46 \pm 10.19$ & $<0.001$ \\
\hline
\end{tabular}

Table 2. Univariate and multivariate regression analysis of predictors of in-hospital mortality<

\begin{tabular}{|c|c|c|c|c|c|c|}
\hline \multirow[b]{2}{*}{ Variables } & \multicolumn{3}{|c|}{ Univariate } & \multicolumn{3}{|c|}{ Multivariate } \\
\hline & $\mathbf{p}$ & HR & $95 \% \mathrm{Cl}$ & $\mathbf{p}$ & HR & $95 \% \mathrm{Cl}$ \\
\hline WBC count & 0.877 & 0.992 & $0.900-1.095$ & & & \\
\hline Neutrophil count & 0.971 & 0.998 & $0.906-1.100$ & & & \\
\hline Lymphocyte count & 0.266 & 0.657 & $0.314-1.376$ & & & \\
\hline Trombosit count & 0.757 & 0.999 & $0.994-1.004$ & & & \\
\hline SII & 0.580 & 1000 & $1.000-1.000$ & & & \\
\hline CRP & 0.003 & 1.078 & $1.025-1.133$ & 0.01 & 1.111 & $1.025-1.204$ \\
\hline
\end{tabular}




\section{DISCUSSION}

As a result of our study, we showed that SII, NLR and CRP values, which can be easily obtained in the clinic, can be used to predict in-hospital mortality in patients with Covid-19 disease who had previously undergone $\mathrm{PCl}$ with the diagnosis of CAD. Although SII and NLR values were not related with in-hospital prognosis; a strong and significant relationship exists between CRP values and prognosis. The increase in the number of cases and hospitalizations due to the diagnosis of Covid-19 day by day in parallel with the increase in the rate of hospitalizations will cause additional burden on the health system and delay provision of health care for newly diagnosed patients with Covid-19. ${ }^{[7]}$

Additional clinical problems accompanying hospitalizations are associated with long-term hospital stays and increased mortality rates, and especially systemic diseases such as HT, $\mathrm{DM}, \mathrm{CVD}$ and stroke affect the clinical picture negatively. ${ }^{[8-10]}$

As an inflammatory disease atherosclerosis is the most important underlying pathology of CAD. Blood serum levels of inflammatory markers may vary depending on the severity of the disease and other accompanying comorbid conditions. In clinical practice CRP and hemogram parameters per se, and the new parameters obtained from the combination of various parameters have been shown to be associated with the prognosis of cardiac and noncardiac diseases. ${ }^{[1]}$ In the study by Dursun et al. the authors showed the relationship between CRP levels and the Gensini scores used as indicators of the severity of coronary lesion. ${ }^{[12]}$ Similarly, Luo et al. showed that increased CRP values in stable coronary artery disease are associated with all -cause mortality. ${ }^{[13]}$ Similar to the studies investigating the correlation between atherosclerosis and CRP values, in our study, increased CRP values were found to be associated with in-hospital mortality in patients with Covid-19 with a history of CAD. In the literature; NLR has been associated with the severity of CAD and long-term prognosis. In a retrospective study with 737 patients by Yang et al., NLR values correlated with the severity of coronary artery lesions, but not with adverse cardiovascular outcomes. ${ }^{[14]}$ In our study, although the NLR values were numerically higher in the group with inhospital mortality, NLR was unusable in predicting prognosis. In addition to known and frequently used markers, SIl, which we have recently had information about in current studies, is a new and useful biomarker and its usability in the prognosis of patients with malignancy has been tested. ${ }^{[15]}$ However, in our study, it was not useful in predicting mortality in the short term.

Yang et al. showed that thrombocytopenia was associated with increased mortality in patients with Covid-19 disease, however in our study any statistically significant intergroup difference was not observed and any relationship with short-term mortality could not be demonstrated. ${ }^{[16]}$ It has been suggested that the development of thrombocytopenia and increased hematopoiesis after bone marrow infection in patients with severe acute respiratory syndrome (SARS) may also occur with the same mechanisms in patients with Covid-19 disease. ${ }^{[17]}$
The differences in our study and in the literature suggest that different receptors and mechanisms in patients with Covid-19 disease are still not fully elucidated.

Our biggest limitation is that our study was a single centered trial conducted with a small number of patients. Another limitation is that any distinction was not made among our study patients in terms of the length and diameter of the coronary stents implanted and whether or not they were drug-eluted stents. In addition, since in our study routine autopsy was not performed in patients who did not survive, our knowledge on the extent of myocardial damage is limited. Prospective multicenter studies should be performed so as to support the results we obtained in our study.

\section{CONCLUSION}

Simple and useful markers such as CRP and hemoglobin can be used to predict in-hospital mortality in patients with the diagnosis of Covid-19 disease, especially if there is a history of $\mathrm{PCl}$ applied for CAD.

In addition, in line with the results of our study, patients with a CRP of $\geq 3.1$ should be monitored closely in terms of sudden unexpected deaths.

\section{ETHICAL DECLARATIONS}

Ethics Committee Approval: Ministry of Health and the ethics committee of our institution, and our study was carried out in accordance with Principles of the Helsinki Declaration (Decision no: 2020-14).

Informed Consent: Written consent was obtained from all patients who participated in the study and their relatives.

Referee Evaluation Process: Externally peer-reviewed.

Conflict of Interest Statement: The author(s) declared no potential conflicts of interest with respect to the research, authorship, and/or publication of this article.

Financial Disclosure: The authors declared that this study has received no financial support.

\section{REFERENCES}

1. Zhou P, Yang XL, Wang XG, Hu B, Zhang L, Zhang W, et al. A pneumonia outbreak associated with a new coronavirus of probable bat origin. Nature. 2020;579(7798):270-73.

2. Huang C, Wang Y, Li X, Ren L, Zhao J, Hu Y, et al. Clinical features of patients infected with 2019 novel coronavirus in Wuhan, China. Lancet. 2020;395:497-506.

3. Vincent JL, Moreno R, Takala J, Willatts S, De Mendonça A, Bruining H, et al. The SOFA (Sepsis-related organ failure assessment) score to describe organ dysfunction/failure. On be- half of the working group on Sepsisrelated problems of the European society of intensive care medicine. Intensive Care Med. 1996;22:707-10.

4. Tang N, Li D, Wang X, Sun Z. Abnormal coagulation parameters are associated with poor prognosis in patients with novel coronavirus pneumonia. J Thromb Haemost. 2020;18(4):844-47.

5. Gupta R, Joshi P, Mohan V, Reddy KS, Yusuf S. Epidemiology and causation of coronary heart disease and stroke in India. Heart 2008;94:16-26. 
6. Habib SS, Kurdi MI, Aseri ZA, Suriya MO. CRP levels are higher in patients with ST elevation than non-ST elevation acute coronary syndrome. Arq Bras Cardiol 2011;961:13-7.

7. Baiyewu O, Elugbadebo O, Oshodi Y. Burden of Covid-19 on mental health of older adults in a fragile healthcare system: the case of Nigeria: dealing with inequalities and inadequacies. Int Psychogeriatr. 2020;32(10):118185.

8. Hussain A, Bhowmik B, do Vale Moreira NC. Covid-19 and diabetes: Knowledge in progress. Diabetes Res Clin Pract. 2020;162:108142.

9. Schiffrin EL, Flack JM, Ito $S$, Muntner P, Webb RC. Hypertension and Covid-19. Am J Hypertens. 2020;33(5):373-74.

10. Villa E, Saccocci M, Messina A, Maffeo D, Pitì A, Bianchetti F, et al. Covid-19 e coronaropatia: uso selettivo e collaborativo delle risorse durante le crisi sanitarie [Covid-19 and coronary artery disease: selective and collaborative use of resources during public health crisis]. G Ital Cardiol (Rome). 2020;21(5):360-63.

11. Swiatkiewicz I, Kozinski M, Magielski P, Fabiszak T, Sukiennik EP, Navarese $E P$, et al. Value of CRP in predicting left ventricular remodeling in patients with a first ST-segment elevation myocar- dial infarction. Mediators Inflamm 2012;2012:250867.

12. Dursun I, Kul S, Bayraktar A, Erkan H, Turan T, Sayin MR, et al. Association of Aortic Valve Sclerosis and Clinical Factors in Patients With Acute Myocardial Infarction. Am J Med Sci. 2019;357(6):474-82.

13. Luo F, Feng C, Zhuo C. C-Reactive Protein and All-Cause Mortality in Patients with Stable Coronary Artery Disease: A Secondary Analysis Based on a Retrospective Cohort Study. Med Sci Monit. 2019;25:9820-28.

14. Yang $Y, X u Y$, Wang J, Zhai $X$, Jiang $H$. Predictive efficacy of neutrophil-tolymphocyte ratio for long-term prognosis in new onset acute coronary syndrome: a retrospective cohort study. BMC Cardiovasc Disord. 2020;20(1):500

15. Chen JH, Zhai ET, Yuan YJ, Wu KM, Xu JB, Peng JJ, et al. Systemic immuneinflammation index for predicting prognosis of colorectal cancer. World J Gastroenterol. 2017;23(34):6261-272.

16. Yang, X., Yang, Q., Wang, Y., Wu, Y., Xu, J., Yu, Y, et al. Thrombocytopenia and its association with mortality in patients with Covid-19. J Thromb Haemost. 2020;18(6):1469-72.

17. Xu P, Zhou Q, Xu J. Mechanism of thrombocytopenia in Covid-19 patients. Ann Hematol. 2020;99(6):1205-08. 